\title{
Women's reflections on choosing quality long day care in a regional community
}

\author{
Nonie Harris \\ James Cook University of North Queensland
}

THIS ARTICLE QUALITATIVELY EXPLORES women's experiences of choosing quality long day care in a regional community. The study complements recent quantitative research on the quality implications of increased for-profit childcare provision. It also adds to our understanding of current childcare policy by focusing on the experiences of women in a regional location. The women in this study associated the expansion of the corporate childcare sector with a decline in care quality and claimed that the 'market' approach to child care provision had diminished their choices. Corporate, one-size-fits-all child care services, managed in distant capital cities, were seen to be unresponsive to the needs of their regional community. These results challenge the Federal Government's rhetoric on child care choice and encourage policy-makers to re-examine the quality implications of a dominant corporate care sector.

\section{Introduction}

AUSTRALIAN PARENTS are grappling with what to many experts in early childhood education is a fundamental paradox-quality child care and corporate profit (Goodfellow, 2005). In the national media, parents question the quality of care in corporate childcare centres (Australian Broadcasting Corporation, 2006). In 2005 L.ynne Wannan, the Convenor of the National Association of Community-based Services, asserted that child care quality has become a secondary consideration and, further, that 'opening up the market has not led to increased competition, lower prices and improved quality' (p. 2). According to Elliott (2006), the number of private for-profit childcare centres grew by at least 201 per cent from 1991 to 2004. In contrast, the number of not-forprofit community-based childcare centres grew by 35 per cent in the same period. In regional Australia the changes have been just as dramatic. In the Townsville region, the site of this research, in 2000 there were 12 communitybased centres and 28 independently-owned centres, and corporate childcare chains owned seven per cent of these (Townsville and District Early Childhood Association, 2000). Today in the Townsville region there are still 12 communitybased centres, but now there are 44 independently-owned centres, with 68 per cent of these owned by corporate childcare chains. In light of the debate on quality child care and corporate profit I was concerned about what these changes might mean for regional women's choice of quality long day care services.

Similar concerns have recently been shared by other researchers, who have asked if the pursuit of profit by corporate childcare providers is compatible with the provision of high-quality care services (Rush, 2005). There is a salience to these concerns as, in 2004, 383,020 Australian children were using underschool-age centrebased long day care, and two-thirds of these children were using care provided by for-profit childcare centres (Commonwealth Department of Family and Community Services, 2004; Rush, 2005). In a 2006 online survey undertaken by Choice magazine, parents reported that, once they had located care (a difficult process in itself). many of them had experienced high staff turnover, inadequate staff-child ratios, and unsuitably qualified staff. Parents with these concerns about quality were most likely to be using commercially-operated childcare centres (Choice, 2006). Rush (2006) from the Australia institute, an independent public policy research centre, aiso found a link between child care quality and type of provider. The 578 childcare staff surveyed in Rush's quality-focused study reported that, in their experience, the highest-quality care was provided by community-based centres and the lowest by corporate chains (Rush, 2006). 
The qualitative data presented in this paper complements these recent quantitative studies and adds to our understanding of current childcare policy by focusing on the experiences of women in a regional location. The objective of this research is to explore women's experiences of choosing quality long day care in a landscape that privileges for-profit child care solutions. The regional context of women's experiences is emphasised. The purpose of this exploration is to provide evidence from which to critique and inform childcare policy. The aims of this research project are consistent with childcare literature that encourages researchers to look for emerging representations of child care and also to position childcare issues in a range of gender equity and social justice discourses (Fincher, 1996).

This research focuses on long day care quality. The 2004 Child Care Census reported that 51 per cent of children using formal child care were using long day care services, making it the most frequently used type of childcare service. In Australia formal or regulated early childhood services are provided by long day care centres, family day care, out-of-school-hours programs including vacation care, and occasional childcare services. In recent years the increased demand for child care has meant an expansion of all these service types, particularly long day care and outside-schoolhours care programs (Elliott, 2006). The Commonwealth Department of Families, Community Services and Indigenous Affairs ( $\mathrm{FaCS} \mid \mathrm{A}$ ) defines long day care as care 'provided in day care centres mainly for children up to school age. These centres may also call themselves kindergartens, preschools, childcare centres, or early learning centres' (2007b, p. 1).

I assume in this paper that long day care is operated by three groups of providers: community-based non-profit; small independent for-profit; and for-profit corporate chains (Rush, 2006). City councils, community groups and similar organisations operate community-based centres. Independently-owned for-profit centres are operated by small, owner-operated businesses that, in the majority of cases, own no more than one centre. Rush defines corporate chains as those child care providers that are listed on the Australian Stock Exchange' (p. 2). The largest of these is $A B C$ Learning Centres which, according to its 2006 Annual Report, operated 905 long day care centres in Australia-' $20 \%$ of long day cares nationally' (ABC Learning Centres Limited, 2006, p. 7). It is interesting to note that in the Townsvilie region $A B C$ Learning Centres operates 50 per cent of long day care centres (Community Information Centre, 2006).

In this article I have also chosen to focus on the qualitative experiences of women. Elsewhere, (Harris, 2007), I have argued that current 'family'-centred social policy discourses tend to reinforce the invisibility of women's gendered disadvantage. Often there is no public linking of women's needs to the provision of services, such as child care, that have a great impact on their lives. Further, Bennett argues, 'child care reflects the high degree of ambiguity that the welfare state holds for women ... it reflects the degree to which women are subordinate as citizens and relegated to the private domain as it suits the goals of the state' $(2001$, p. 35). Recent quantitative research undertaken by Choice magazine (2006) also supports this focus on women-88 per cent of their self-selecting respondents were female. Women in my study also claimed:

This is a matter close to women's hearts. And it needs to be talked about before all the men in power put their spin on it.

Because of the immense guilt and society pressure on leaving children-for mums it's really hard... You know, do I work or do / stay at home-if l've got to go to work how good's the child care? Mums spend a lot of time thinking about their children - how are they feeling, are they happy?

\section{A brief history of relevant childcare policy}

In the early 1980s governments used the emerging economic rationalist agenda to justify the move away from publicly-funded community-based child care. Initially ministers, such as Neal Blewitt in the Hawke Government, were able to use economic arguments to support publicly-funded child care. In 1987 Neal Blewitt commissioned a study from the Centre for Economic Policy Research (CEPR) that detailed the economic benefits of publicly-funded care. The National Child Care Strategy that followed used this economic data to ensure that government-funded operational and fee relief subsidies to childcare services were maintained. At this time these subsidies could not be used to support either for-profit childcare services or to subsidise the cost of care at for-profit centres. Under this strategy child care places were increased in community-based centres, family day care, occasional care and out-ofschool care services. However, the cost-cutting agenda of the Labor Government soon reasserted itself and less expensive options to meet childcare needs were expiored. Family day care and commercial childcare centres were now viewed as potentially more 'cost effective' ways to meet increasing child care demand (Brennan, 1998, p. 189).

In the 1980s the commercial childcare sector also began to lobby the government to extend fee relief to the users of their centres. The pressure from this lobby group, and also the pressure to reduce government spending on child care, led to an announcement in the 1990 election campaign that, if re-elected, the Labor Government would extend subsidies to parents using commercial 
childcare centres. The Labor Government was returned to power and this policy was implemented, with the addition of some quality assurance mechanisms. These were put into practice in 1994 and required long day care centres to be accredited if the parents using the centre were to be eligible for subsidy payments.

In 1997 the newly-elected Liberal/National Coalition Government continued the process of shifting subsidies to parents. In July 1997 it withdrew operational funding from community-based centres and out-of-schoolhours care in 1998) and replaced fee relief and the child care cash rebate with a single subsidy payment to parents. This subsidy, known as the Child Care Benefit (CCB), could be used to assist with the cost of care in registered formal and informal child care arrangements. Brennan saw this change as a 'move away from supply-side subsidies (such as capital and operational assistance to service providers) and towards encouraging competition between commercial and non-profit providers by subsidising consumer demand' (1998, p. 213). And the reality is that, under this subsidy policy, the private forprofit childcare sector has grown enormously,

Bennett also argues that in the 1990s the Australian Government 'pursued the marketisation of child care ...' (2001, p. 33) by withdrawing childcare provider funding in favour of direct subsidies to parents. Nevertheless, the earlier and continued redirection of childcare funding represented a significant change to the structure of child care provision' (Romeril, 2002, p. 6) leading to the rise of the for-profit sector with consequent impact on both the supply and quality of care (Brennan, 2002).

\section{Long day care quality}

The Commonwealth and state and territory governments share the regulation of child care quality. The Commonwealth Government maintains that it is committed to supporting the provision of high-quality care through 'a formal quality assurance system' (Commonweaith Department of FaCSIA, 2007 a, p. 1). The Commonwealth therefore funds the National Childcare Accreditation Council to administer an accreditation system that focuses on 'staff practices and actual outcomes for children' (Rush, 2006, p. 9). Long day care centres need to be accredited in order to be eligible to receive $\mathrm{CCB}$. However, that accreditation is not mandatory and not all childcare providers are accredited.

State and territory governments are responsible for licensing childcare facilities. In Queensland the Department of Communities regulates minimum standards for childcare services under the Child Care Act (Department of Communities, 2007). The intention of the Act is to promote the best interests of the child by ensuring the safety and suitability of buildings and facilities, adequate staff-child ratios and appropriate staff qualifications (Rush, 2006).

Both Rush and Elliott express concerns about these federal and state quality assurances systems, maintaining they are complex, inconsistent across jurisdictions, and provide no coherent national quality framework in early childhood education. Elliott also reminds us that, 'To date there is no process for monitoring or reporting on developmental outcomes for young children within early childhood services and little Australian evidence to inform discussion about the impact of early childhood programs on children's growth and development' (2006, p. 3).

\section{A regional community}

Baum, O'Connor and Stimson define regional centres such as Townsville as large non-metropolitan cities where the population is greater than 10,000 and the majority of the population is defined as urban. Townsville is more specifically labelled as a servicebased advantaged centre with 'diverse socio-economic characteristics' $(2005$, p. 04.10). These centres are doing weil economically and have low unemployment rates, high workforce participation rates, and above the Australian average of educated professionals. The community income level is slightly higher than average Australian wage level, although there are pockets of disadvantage above the Australian average.

More specifically, the Townsville region is situated on the northeast tropical coast of Queensland and consists of two regional cities, Townsvilie and Thuringowa, which rely on a variety of industry and public sectors such as health, public administration, higher education, pastoral, mining, tourism and defence. Significantly, this has meant residential mobility in the Townsville region is particularly high, with many families moving in and out of the region (Community and Cultural Services Department, 2003). The region has also, in recent years, recorded strong population growth fcurrent population is approximately 154,000 ), with 31.6 per cent of the population aged between 25 and 44 years (Australian Bureau of Statistics, 2003). It is worth noting that the age profile of residents is lower than that of Queensland and Australia as a whole.

\section{Interviewing women}

Twenty in-depth qualitative interviews were conducted with women from the Townsville region in late 2006 and early 2007. Women were recruited on a voluntary basis through the distribution of recruitment flyers to 22 long day care centres, the university, two public libraries and a women's centre. Flyers were distributed to eight community-based centres and 14 for-profit childcare centres. This qualitative study was intended 
to be an in-depth exploration of Townsville women's experience and is neither statistically representative nor generalisable. This research was funded by a grant from the Don Chipp Foundation and received ethics approval from James Cook University's Human Ethics Committee.

The majority of women who participated in this study worked part-time, and they tended to work in the service and 'caring' sectors as childcare workers, teachers, nurses, and in-office administration. Additionaily, one woman was an engineer, three were students and two were not in paid employment. All the women were nonIndigenous, though one woman's child was indigenous. The women had an average of 1.5 children in child care and the children's ages ranged from four months to nine years. Most of the women were using part-time care and had been using care for periods greater than two years. The majority of women were married and one woman was in a same-sex relationship. Fourteen women were using community-based child care, two were using small independently-owned centres, and five had placed their children in corporate childcare centres. One woman used both community-based and corporate child care.

Interviews with women were semi-structured and based on a flexible interview schedule. Questions focused on current child care arrangements, experience of locating care, criteria for choosing current care arrangement, vision of ideal child care quality, perceptions of quality over time, the 'market' as a mechanism for ensuring the choice of quality care, and reflections on the changing childcare landscape. No questions directly focused on the corporate childcare sector.

Women were passionate about care quality and having an opportunity to participate in a study about this. Some women became teary during their interviews.

That's why I wanted to talk to you, like, I get really angry about the quality stuff ... I don't read good, so the [childcare worker] told me about your interviews and I said to her I wanted to tell you about what really matters to me and mums like me.

But it taps so deeply into what it means to be a mother, to care, to nurture your child. Child care is a deeply emotional and difficult thing because you are actually looking for someone to replace you ... So child care is a powerful topic and until you open up that window you have no idea just how powerful it can be. It's just child care until it's about the care of your child.

\section{Women's reflections}

In this section I have primarily presented the words of the women who participated in this research. This data presentation strategy is consistent with feminist research goals that value women's accounts of their own experiences, sharing women's knowledge and exploring experiences relevant to women's lives (Oakley, 1979). These goals are concerned with making women and their experiences visible and promoting social change (Roberts, 1981).

\section{Locating quality long day care}

Australian Bureau of Statistics (ABS) data indicates that the number of children in formal child care continues to increase and the demand for such care is, overall, higher than the supply. The number of children waiting for formal care places is difficult to measure. Childcare centre waiting list data is often an unreliable predictor of demand, as parents tend to place their children's names on multiple waiting lists. The ABS, however, sought to clarify demand by asking parents 'not using formal child care ... if they would have liked to use it if it were available' $(2003$, p. 5). Of parents who were currentiy using informal care, six per cent reported that they would prefer formal care (involving 174,500 children).

Most women in this study reported that locating the long day care they wanted was a difficult experience that required substantial time and effort on their part:

It was really, really hard. I think it was about 18-20 centres before I was able to get a place.

More than half the women noticed that the waiting lists at community-based centres were particularly long, and they related the length of the waiting list to the quality of the child care provided:

I could not for love or money get her into (a communitybased centre). A huge waiting list-renowned for its excellence-just can't get them in. And another thing -you know when a centre is good or not-if you can get your child straight in there it's not good ... and if it's got a waiting list you know it's a good centre.

Quality of care was the criterion most frequently given by women for choosing their childcare arrangement:

When you hand over to someone else-it's the hardest thing. Harder than no sleep! And I couldn'tI'd be sick to my guts if the place didn't feel right. No matter how pretty it looked.

Nine of the 20 women who participated in the study indicated that when searching for child care they would not consider approaching a corporate long day care centre:

I didn't even look at the big multi-nationals. I really wanted to steer away from that supermarket child care thinking. 
For many of the women, visiting corporate childcare centres was not a positive experience:

You just walked in and it spoke dollars ... I know you do the attending [to children], but what are you going to do to develop the kids ... and there was nothing; it was just cold and money and so / said you can shove that.

These difficulties in locating child care meant that some women initially placed their children in care centres they were not happy with. Six of the women had initially placed their children in corporate centres and subsequently moved them because of concerns about quality. None of the women had removed their children from community-based or independently-owned centres-although one mother was concerned about the quality of care her child was receiving in a community-based centre. The unique flexibility of hours and fee structures at that centre meant she could not afford to place her child in a less flexible but higherquality centre.

All the women had a clear vision of their ideal quality childcare service-perhaps best summed up in the following quote:

Quality is about really connecting with children--.. getting down in the dirt and really caring.

Only nine of the women indicated that their current childcare service met their ideal quality vision. One of these women was using a corporate centre and two were using independently-owned centres. Eight women reported that their centre partly met their ideal quality vision, and four were using centres that did not meet their quality vision at all. Three of the four were using corporate childcare centres. Their quality concerns were about lack of age-appropriate learning opportunities, high staff turnover, insufficient stimulating activities, high staff-child ratios, lack of a warm and caring atmosphere, unhappy staff, and high use of TV and video games.

\section{The 'market' and choosing quality child care}

Recently Mal Brough, the then Minister for Families, Community Services and Indigenous Affairs, claimed: 'The Australian Government supports families in the choices they make about appropriate child care for their children and this system (non-profit and for-profit providers) allows parents to choose which child care service meets their needs' $(2006, p .3)$. This comment illustrates the Federal Government's focus at that time on 'consumer choice' and its assumption that childcare choice is linked to the provision of services by a mix of for-profit and non-profit providers. The government supported parents' 'choice' through the CCB--payable on a sliding fee scale to registered providers chosen by parents. The government therefore sought to establish, through its provision of subsidies (the CCB), a responsive market-driven sector that was encouraged by parent demand to establish centres where parents needed them and quality care at a price they can afford. Deborah Brennan (1998) describes this emphasis on consumer choice as a 'market rules' approach.

However, the women in this research project equated the 'market' with the unfettered expansion of the for-profit childcare sector, rather than a mechanism responsive to their care needs. None of the women interviewed thought that the 'market' would ensure that they would have access to improved quality of care.

I don't think the market provides. I think the market controls; really, it's a beast, this thing that takes choice away a lot of times, like, you know, I get frustrated by it; everything is global, nothing's local, where ... ooh, it just shits me ... sorry!

If the market was going to give us quality child care then it would need to be an environment where we could all boycott the places that were crap! But you can't do that if the only places are in the crap service. What do you do then? And it's harder, say, when you are a new mother and you don't know the place is crap.

Many women thought linking parental demand and quality was flawed, as such a link assumed that there would be a range of quality childcare options to choose from. This was not their experience:

Quality child care is not necessarily a range of choices unless the range of choices are so large that you can really shop around. I think a range of choices-l just sort of think of being in a shop and just picking, this aisle, shop, this aisle, shop. But the reality is this is not what it's like for child care.

Women felt that the domination of the Townsville childcare market by corporate care providers had in reality diminished choice:

I think $A B C$ almost owns every single child care in Townsville. They probably will eventually have them all, I'm sure. So you are not getting a wider range you can choose from-it's $A B C, A B C$ or $A B C$.

\section{The changing long day care landscape}

The women in this study were aware that over the past decade there had been dramatic changes to the childcare landscape. They had noticed the expansion of corporate childcare providers in their local communities and linked this expansion to their opportunities to choose quality care:

I'm very concerned - I would automatically avoid a for-profit centre if I possibly could because I have concerns that children and profit don't mix ... profit is their ultimate aim and quality child care is not. 
I think it's concerning industry-wise ... I think the kind of domino effect takes a while to actually translate into what children are experiencing. It's like a lot of industries where one particular brand gets the monopoly and there is a danger of churning out little robots ... they're all going to experience the McDonald's climbing frame and the push-and-pull toy because we buy them in bulk from America and ship them in bulk and put them in every centre... there's a great danger there--lost that community feel of what makes our centre special.

Some women reflected on the broader childcare policy landscape and the motivations of governments:

I wonder whether the fact that there hasn't been an increase in community-based centres, particularly in a place like Townsville... is a reluctance on behalf of councils to actually increase their number of centres by saying we'll just let the private sector look after it because we don't want to bother.

\section{Quality long day care in the Townsville region}

The Townsville City Council has supported local childcare services since the establishment of the first day nursery in the city in 1947. The council saw child care as providing a generic support for families by 'building relationships, providing information, and being there when things get difficult' (Community Services Manager, 2001). This community-centred child care vision underpinned the council's strong support for a range of community-based care programs. However, since the loss of capital and operational subsidies in 1997 no new community-based childcare programs have been established in the region.

The women in this study valued their childcare service's link to their local community. As previously noted, family mobility levels in the Townsville region are relatively high. Many families have moved to the region for work reasons and, consequently, often have no extended family support. Two-thirds of the respondents in this study reported that they had no extended family in Townsville. These women, therefore, were particularly reliant on formal child care arrangements and commented on the importance of such care in the absence of family:

A lot of families are more isolated nowadays especially in Townsville with the RAAF and the armed forces. I've noticed that a lot of people here don't have anyone, family, at all, and it makes it even harder.

Involvement in community-based childcare services could help alleviate this social isolation:

And so being able to take her to kindy and then being able to find a place for myself within that kindy... I think a lot of people are new to Townsville and you might normally make friends at work-but if you have really little children-it's a way, sort of a structure that enables you to do that.

However, some women's sense of isolation was intensified by the centralised management practices of corporate childcare centres:

Because it's that whole thing about community... I'll just lend upl talking to someone in Brisbane ... and they know nothing about Townsville, nothing about my family, don't know me.

The following reflection summarises women's concerns about community connection and corporate child care:

Townsville's a very family-oriented city and I think the government could build on that and create more opportunities for families to be a part of their community. Child care should be a community service, not something to make someone else money ... but of course it isn't mums who are seen to know and care about child care-it's a big bloke from down south who probably never had to juggle a three-month-old with an ear infection, a two-anda-half year old with energy to burn, and a mum that just has to go to the bank! So they set up the services that aren't really practical.

\section{Discussion: quality, profit and community}

The women who participated in this study are profoundly committed to their children's right to a high-quality long day care environment. They have a strong vision of what quality child care is-a community-centred service where children's needs are the priority. Of particular interest is the link made by respondents between quality experiences and the rise of the corporate childcare sector. This link was made without specific mention of the corporate sector during the research process. The majority of women believed that quality child care and the pursuit of profits are incompatible goals and, further, as the corporate sector has expanded, their opportunities to choose quality care have diminished. It appears that responses reflected Deborah Brennan's claim that corporate operators are 'simply profit-seekers, cutting costs and exploiting families ... at every turn' (1998, p. 214). It should be noted that only two women in this study were satisfied or partially satisfied with the quality of care provided in their corporate-owned childcare centres and only one was dissatisfied with the quality of care in her community-based centre.

The majority of women's reflections, though, were consistent with the findings of Emma Rush's quantitative study, Child Care Quality in Australia and Choice magazine's 2006 online survey. The Choice survey did not, however, differentiate between corporate and small independently-owned for-profit providers. The for- 
profit childcare sector is not a homogenous entity, and Brennan (1998) claims that in general there is a strong commitment to quality in independentiy-owned long day care centres. Rush supports this assertion and argues that it is not necessarily 'forprofit' status that negatively impacts on quality; rather it is the 'governance structures associated with publicly listed corporate chains. These structures elevate financial objectives to the detriment of humanist concerns' $(2006$, p. 59). In this study both the women using independently-owned centres reported that these centres fully met their quality vision.

The assertion that corporate profit and quality child care are incompatible was contested by the former Minister for Families, Community Services and Indigenous Affairs, Mal Brough, who argued that the government's commitment to quality was evident in its Child Care Compliance Strategy and a 'major overhau of the accreditation regime to ensure that parents have confidence in the system' $(2006$, p. 1$)$. In this statement $\mathrm{Mr}$ Brough assumed the legitimacy of the current childcare provision system and, further, that care quality is assured by an improved accreditation system alone. rather than in association with a critical examination of the current long day care delivery structures.

The then Commonwealth Government also continued to reassert its commitment to the 'market rules' approach to child care. It maintained that the current care delivery mechanisms, largely financed through the CCB, are designed to 'give people choice' (Brough. $2007 a, p .1)$. For the women in this study, however, the 'market' did not provide them with a range of quality child care providers to choose from, nor empower them to contribute to quality by selecting centres that provided the best care. In apparent contradiction to the government's choice rhetoric, and consistent with the women's experiences, Mal Brough candidly commented on the economic reality of child care choice: 'It's nonsensical to have every style of child care available in every suburb, from which parents can then choose. It makes no economic sense' $(2007$ b, p. 1). But the Townsville women claimed that the government used the 'market' as a mechanism, under the guise of consumer choice, for supporting the unaccountable growth of the corporate childcare sector and to avoid funding community-based childcare services

Thus far the Townsville women's reflections have reinforced the findings of recent quantitative research (Choice, 2006; Rush, 2006). However, new understandings have emerged about the implications for regional women of current child care policy. I argue, from the data presented in this paper, that regional context uniquely shapes women's care quality experiences. Townsville is a prosperous service-based advantaged centre with high population growth and high levels of residential mobility. This regional profile has created a high demand for child care that was not able to be easily met by established communitybased care infrastructure. Consequently, in the absence of government support for new communitybased programs, opportunities have been created for the corporate childcare sector to establish itself in a significant way. The women in this study had noticed the expansion of corporate providers in Townsville and associated this expansion with lower child care quality and diminished choice--particularly in newer suburbs where corporate-owned centres dominate. Townsville's high level of residential mobility and consequent lack of extended family support also meant that many women in this study valued childcare services that were linked to their community. However, in many cases their experiences were corporate, one-size-fits-all services, managed in distant capital cities and unresponsive to the needs of their regional community.

The experiences and concerns of the Townsville women who participated in this study may not be exclusively linked to their regional location. However, I argue, the regional context with its associated high levels of growth and mobility, isolation from family support, and rapidly expanding corporate childcare sector, increases regional women's vulnerability to diminished opportunities to choose quality long day care services. This finding has highlighted an important area for further research, and 1 recommend a continued focus on regional women's experiences of choosing quality child care.

\section{Conclusion}

Carol Bacchi argues: 'The language of choice in this case (concerning childcare policy) also suggests a minimal role for government in "private" lives, neglecting the way in which this kind of policy creates the conditions which will shape people's lives' (Bacchi, 1999, p. 140). Bacchi's argument reinforces the importance of focusing on the implications of childcare policies that privilege for-profit solutions. For the women in this study child care quality was indeed 'a matter close to women's hearts' and their passion for quality shone through in their interviews. There are lessons for the government to learn from these women's stories. The women valued child care quality and they wanted their care services to be part of their communities. They saw a role for government in supporting quality, community-centred care. The Federal Government at the time's goal of giving parents child care choice will not be achieved, according to the women in this study, through policies that encourage the unaccountable expansion of the corporate childcare sector. Rather, genuine choice for regional women will be achieved through a thoughtful combination of increased childcare subsidies for parents, consistent and cohesive licensing and accreditation systems, and the reinstatement of capital and operational funding for the community-based childcare sector. 


\section{References}

ABC Learning Centres Limited (2006). Annual report 2006. Brisbane.

Australian Broadcasting Corporation (2006). Parents question quality of care at $A B C$ Learning Centres. The 7.30 Report. Retrieved 26 April 2006, www.abc.net.au/7.30/content/2006/ s1622919.htm.

Australian Bureau of Statistics (2003). 4402.0 child care, Australia. Canberra: Australian Bureau of Statistics.

Bacchi, C. (1999). Women, policy and politics: The construction of policy problems. London: Sage Publications.

Baum, S., O'Connor, K., \& Stimson, R. (2005). Fault lines exposed: Advantage and disadvantage across Australia's settlement system. Sydney: Monash University Press.

Bennett, L. (2001). Precarious but tenacious: Child care and local government in the Kennett era. Just Policy, 23(September), 33-41.

Brennan, D. (1998). The politics of Australian child care: Philanthrooy to feminism and beyond (Revised edn). Cambridge: Cambridge University Press.

Brennan, D. (2002). Australia: Child care and state-centred feminism in a liberal welfare regime. In S. Michel \& R. Mahon (Eds.). Child care policy at the crossroads: Gender and welfare state restructuring (pp. 95-112). New York: Routledge.

Brough, M. (2006). Choice magazine survey paints incorrect picture. Media Release. Retrieved 2 April 2007, www.facsia. gov.au/internet/minister3.nsf/content/choice_release_..310ct06. htm.

Brough, M. (2007a). Child care forces 100,000 out of work. News.com.au. Retrieved 20 April 2007, www.news.com.au story/0,10117,21460224-1702,00.htm

Brough, M. (2007b). Parents feel the pressure. The Australian. Retrieved 15 April 2007, http://theaustralian.news.com.au/ story/0,20867,21435006-28737,00.html.

Choice. (2006). Choice child care survey. Retrieved March 16 2007. www.choice.com.au/viewArticle.aspx?id $=105463 \&$ catid $=100509 \&$ tid $=100008 \& p=1 \&$ title $=$ Childcare.

Commonwealth Department of Family and Community Services (2004). Census of child care services. Canberra: Commonweaith Government.

Commonwealth Department of Families, Community Services and Indigenous Affairs (FaCSiA) (2007a). How do I know my child is attending a quality service? (Fact Sheet 15). Retrieved April 7 2007, www.facsia.gov.au/internet/facsinternet.nsf/NIA childcare/\$File/factsheet15.pdf.

Commonwealth Department of Families, Community Services and Indigenous Affairs (FaCSIA) $(2007 \mathrm{~b})$. What are the differen types of approved child care? (Fact Sheet 4). Retrieved April 7 2007, www.facsia.gov.au/internet/facsinternet.nsf/NIA childcare/\$File/factsheet4.pdf.

Community and Cultural Services Department (2003). The Townsville region: A social atlas ( 5 th edn). Townsville: Townsville City Council.

Community Information Centre (2006). Townsville and Thuringowa community resource directory: October 2006 - September 2007. Townsville: Community Information Centre (Townsville \& District) Inc.

Community Services Manager (2001). Private communication. Townsville City Council, Townsville.
Department of Communities (2007). Legislation information paper. Retrieved April 10 2007, www.communities.qid.gov.au/ childcare/cclegislation/infopaper/

Elliott, A. (2006). Early childhood education: Pathways to quality and equity for all children. Victoria: Australian Councii for Educational Research.

Fincher, R. (1996). The state and child care. In K. England (Ed.), Who will mind the baby: Geographies of child care and working mothers (pp. 143-166). London: Routledge.

Goodfellow, J. (2005). Market childcare: Preliminary considerations of a 'property view' of the child. Contemporary issues in Early Childhood, 6(1), 54-65.

Harris, N. (2007). 'Child care is not a women's issue!' A feminist analysis of child care subsidy policy. Just Policy, 44(June), 45 50

Oakley, A. (1979). From here to maternity: Becoming a mother. Middiesex: Penguin Books.

Roberts, H. (Ed.). (1981). Doing feminist research. London: Routledge \& Kegan Paul Ltd.

Romeril, B. (2002). The growth of large corporate child care chains. News Sheet, (Spring Edition), 6-7.

Rush, E. (2005). Corporate control of child care. The Australia institute, 45(December), 10

Rush, E. (2006). Child care quality in Australia. Discussion Paper Number 84. Canberra: The Australia Institute.

Townsville District Early Childhood Association Inc. (2000). Child care options in Townsville and district. Townsville: Townsville City Council.

Wannan, L. (2005). The changing face of child care in Australia. Melbourne: National Association of Community-based Children's Services Australia. 